\title{
PENGARUH LATIHAN PUSH-UP TERHADAP KEMAMPUAN LEMPAR CAKRAM
}

\section{THE EFFECT OF PUSH-UP EXERCISE ON ABILITY DISCUS THROW}

\author{
Ahmad Lamusu, Zulkifli Lamusu \\ Program Studi Pendidikan Jasmani Olahraga dan Rekreasi, Fakultas Olahraga dan Kesehatan \\ Universitas Negeri Gorontalo \\ Kontak Penulis: ahmadlamusu2020@gmail.com
}

\begin{abstract}
ABSTRAK
Tujuan dari penelitian ini adalah untuk mengetahui seberapa besar pengaruh latihan push-up terhadap kemampuan lempar cakram pada cabang olahraga Atletik Mahasiswa Jurusan Pendidikan Jasmani Kesehatan dan Rekreasi (PJKR) Fakultas Olahraga dan Kesehatan Universitas Negeri Gorontalo. Penelitian ini adalah penelitian experimen murni, untuk mencapai tujuan yang telah dirumuskan maka pemberian perlakuan berdasarkan pada rancangan atau desain penelitian yaitu one group pretest posttest design. Sampel dalam penelitin ini berjumlah 20 orang, dengan selisih perolehan nilai pretest 7,1 (skor tertinggi) dan 4 (skor terendah), sedangkan posttest 8,9 (skor tertinggi) dan 4,1 (skor terendah). Hasil penguji hipotesis menggunakan uji t menghasilkan $t_{\text {hitung }}$ sebesar 18,1 sedangkan dari daftar distribusi diperoleh harga $t_{\text {tabel }} 2,86$. Ternyata harga $t_{\text {hitung }}$ lebih besar dari $t_{\text {tabel }}$. Dengan demikian maka dapat disimpulkan bahwa latihan push-up mempunyai pengaruh yang signifikan terhadap kemampuan lempar cakram.
\end{abstract}

Kata kunci: push up; lempar cakram

\begin{abstract}
The purpose of this study was to determine how much influence push-up exercise has on the ability to throw discs in athletics for students of the Department of Physical Education, Health and Recreation (PJKR) Faculty of Sports and Health, State University of Gorontalo. This research is a pure experimental research, to achieve the objectives that have been formulated, the treatment is based on the research design, namely the one group pretest posttest design. The sample in this study amounted to 20 people, with a difference in the acquisition of pretest scores of 7.1 (highest score) and 4 (lowest score), while posttest 8.9 (highest score) and 4.1 (lowest score). The results of the hypothesis testing using the t-test resulted in a t_count of 18.1 while from the distribution list the t_table value was 2.86. It turns out that the price of t_count is greater than t_table. Thus, it can be concluded that push-up exercise has a significant effect on discus throwing ability.
\end{abstract}

Keywords: push up; discus throw 


\section{PENDAHULUAN}

Pendidikan jasmani pada dasarnya merupakan pendidikan yang mengaktualisasikan seluruh potensi aktivitas manusia berupa sikap, tindak dan karya yang diberi bentuk, isi dan arah menuju kebulatan pribadi sesuai dengan cita-cita kemanusiaan (Dai et al., 2021). Pendidikan jasmani sering diartikan sebagai bagian dari program pendidikan secara umum yang memberikan kontribusi terutama melalui pengalaman gerak terhadap pertumbuhan serta perkembangan manusia secara menyeluruh yang berlangsung seumur hidup (Hadjarati \& Haryanto, 2020). Demikian pula ilmu pengetahuan dan teknologi dibidang keolahragaan merupakan salah satu alat penting untuk merangsang pertumbuhan dan perkembangan tersebut, karena ilmu keolahragaan sangat erat kaitannya dengan gerak manusia yaitu dengan bergerak manusia mampu bertahan hidup dan melalui gerak itulah manusia mencapai beberapa tujuan seperti pertumbuhan fisik, perkembangan mental dan sosial.

Peningkatan prestasi olahraga tidak lepas dari peranan pendekatan ilmiah (Haryanto et al., 2021). Perkembangan ilmu pengetahuan dan teknologi turut berpengaruh dalam meningkatkan prestasi dibidang keolahragaan (Sugiyanto, 2012). Peningkatan ilmu pengetahuan dan teknologi tersebut turut berpengaruh bagi peningkatan prestasi olahraga terutama pada cabang olahraga atletik khususnya nomor lempar cakaram (Wang et al., 2018). Pencapaian prestasi olahraga nomor lempar cakram harus benar-benar memperhatikan secara matang tentang proses pembinaan dan pembibitan sejak dini (Boccia et al., 2019).

Oleh karena itu dalam mencapai prestasi pada nomor lempar cakram secara optimal, seseorang perlu memiliki empat macam kelengkapan dalam pembinaan prestasi olahraga pada umumnya yaitu meliputi: pengembangan fisik, pengembangan teknik, pengembangan mental, dan kematangan juara (Cahyono et al., 2018). Khusus untuk nomor lempar yang diperlombakan baik yang bersifat nasional maupun internasional terdiri dari nomor lempat cakram, lempar lembing, tolak peluru, dan lontar martil. Atletik merupakan kegiatan jasmani yang terdiri dari gerakan-gerakan yang dinamis dan harmonis, yaitu jalan, lari, lompat dan lempar. Atletik merupakan juga sarana untuk pendidikan jasmani dalam upaya meningkatkan kekuatan, daya tahan, kecepatan, kelenturan, kelincahan, koordinasi, dan sebagainya.

Kekuatan otot lengan merupakan penunjang utama dalam melakukan lempar cakram. Apabila otot lengan tidak memiliki kekuatan yang maksimal maka hasil lemparan tidaklah memuaskan. Kekuatan otot lengan dapat ditingkatkan dengan latihan-latihan yang mendukung. Salah satu latihan yang dapat meningkatkan kekuatan otot lengan yaitu dengan latihan push-up. Dengan latihan push-up akan dapat menunjang dalam pembentukan otot serta memiliki daya tahan dan kekuatan otot lengan yang maksimal.

\section{METODE PENELITIAN}

Penelitian ini menggunakan metode penelitian eksperimen dengan rancangan "One Group Pretest and Posttest Design". Test awal (pre-tes), memberikan Treatmen (perlakuan) latihan Push Up dan melakukan test akhir (post-tes), yang kemudian menganalisis selisih skor test awal dan test akhir. Sampel penelitian ini adalah Mahasiswa Jurusan Pendidikan Jasmani Kesehatan 
dan Rekreasi (PJKR) Fakultas Olahraga dan Kesehatan Universitas Negeri Gorontalo yang berjumlah 20 orang.

\section{HASIL PENELITIAN}

Hasil penelitian dalam penelitian ini merupakan fakta empirik untuk mendeskripsikan pengaruh latihan push-up terhadap kemampuan lempar cakram pada cabang olahraga atletik Mahasiswa Jurusan Pendidikan Jasmani Kesehatan dan Rekreasi (PJKR) Fakultas Olahraga dan Kesehatan Universitas Negeri Gorontalo. Dengan jumlah sampel yang diambil dari keseluruhan populasi yang berjumlah 20 orang mahasiswa. Data hasil penlitian berupa skor kemampuan lempar cakram mahasiswa yang diperoleh melalui tes yang diberikan pada mahasiswa. Selanjutnya data tersebut diolah untuk mengetahui normalitas, homogenitas, dan uji hipotetisnya dengan menggunakan statistik uji-t. data hasil penelitian untuk skor kemampuan lempar cakram siswa yang diperoleh pada tes dapat dilihat pada tabel berikut:

Tabel 1. Skor Kemampuan Lempar Cakram Mahasiswa

\begin{tabular}{|c|c|c|c|c|c|c|}
\hline \multirow[t]{2}{*}{ No } & \multirow[t]{2}{*}{ Kelas } & \multirow{2}{*}{$\begin{array}{l}\text { Ukuran } \\
\text { Sampel }\end{array}$} & \multicolumn{2}{|c|}{ Hasil Penilaian } & \multirow{2}{*}{$\begin{array}{c}\text { Rentang } \\
\text { Skor }\end{array}$} & \multirow{2}{*}{$\begin{array}{l}\text { Rata- } \\
\text { rata }\end{array}$} \\
\hline & & & Tertinggi & Terendah & & \\
\hline 1 & Pre Test & 20 & 7,1 & 4 & 3,1 & 5,54 \\
\hline 2 & Post Test & 20 & 8,9 & 4,1 & 4,8 & 7,35 \\
\hline
\end{tabular}

\section{PEMBAHASAN}

Proses pembelajaran dengan mengunakan latihan push-up terhadap kemampuan lempar cakram pada cabang olahraga atletik Mahasiswa Jurusan Pendidikan Jasmani Kesehatan dan Rekreasi (PJKR) Fakultas Olahraga dan Kesehatan Universitas Negeri Gorontalo. Penerapan model latihan ini diawali dengan pemberian suatu penjelasan tentang latihan push-up itu sendiri serta penjelasan tentang lempar cakram pada cabang olahraga atletik. Selanjutnya peneliti mempraktikkan lempar cakram dengan baik dan benar, setelah itu mahasiswa diberikan tugas gerak untuk mencari, belajar, membahas, melatih, dan melakukan lempar cakram yang baik dan benar sebagaimana yang telah dicontohkan.

Hasil analisis deskripitif dan pengujian hipotesis memperhatikan gambaran bahwa latihan push-up mempengaruhi kemampuan lempar cakram pada Mahasiswa Jurusan Pendidikan Jasmani Kesehatan dan Rekreasi (PJKR) Fakultas Olahraga dan Kesehatan Universitas Negeri Gorontalo. Hal ini memberikan indikasi bahwa lempar cakram yang diajarkan dengan latihan push-up mempunyai hasil belajar yang cenderung lebih baik dibandingkan dengan pembelajaran lempar cakram yang tidak diajarkan dengan latihan push-up. Pada perkuliahan dengan model latihan push-up mahasiswa dituntut untuk dapat menemukan jawaban dengan melakukan secara langsung praktek lempar cakram pada cabang olahraga atletik yang dibimbing langsung oleh dosen, namun dalam pelaksanaan ini dosen pengajar tidak berperan aktif tetapi mahasiswalah yang aktif melakukan praktek tentang pembelajaran yang diberikan. Dosen pengajar hanya memberikan gambaran untuk menuntun mahasiswa dalam melakukan kegiatan praktek 
pembelajaran tersebut. Dengan demikian mahasiswa termotivasi untuk berpertisipasi aktif dalam proses perkuliahan.

Dengan demikian dapat disimpulkan bahwa latihan push-up mempengaruhi hasil belajar mahasiswa dalam pembelajaran lempar cakram. Hal ini disebabkan pada latihan push-up mahasiswa berlatih mengembangkan pengetahuan dan keterampilannya untuk melakukan praktek pembelajaran yang benar khususnya yang berhubungan dengan pembelajaran lempar cakram. Cara ini lebih efektif karena memberikan wawasan dan keterampilan bagi mahasiswa untuk berkreasi dalam mengikuti pembelajaran, dan dosen sebagai pembimbing atau pendidik harus mampu untuk memberikan bimbingan dan kesempatan yang seluas-luasnya kepada mahasiswa untuk mengembangkan pengetahuan dan keterampilan serta kreativitasnya agar tercapai hasil belajar yang optimal.

Berdasarkan hasil penelitian pre-test menunjukkan skor tertinggi 7.1 dan skor yang terendah 4. Setelah dilakukan analisis diperoleh nilai rata-rata 5.54 dan nilai standar deviasi 0.79 dan varians 0.63 . Sedangkan pada hasil penelitian post-test menunjukkan skor tertinggi 8.9 dan skor terendah 4.1. Setelah dilakukan analisis diperoleh nilai rata-rata 7.35 dan standar deviasi 1.15 serta varians 1.33. Hal ini menunjukkan bahwa responden yang menjadi sampel dalam penelitian ini memperoleh peningkatan hasil rata-rata dari tes awal sampai tes akhir dengan selisih peningkatan dari hasil Pre-test dan post-test sebesar 1.81 .

Untuk pengujian homogenitas data antara hasil penelitian pre-test dan post-test seluruh variabel memiliki varians populasi yang homogen serta memiliki populasi yang berdistribusi normal. Untuk keperluan pengujian hipotesis dalam penelitian ini, maka dalam pengujian hipotesis digunakan uji analisis data penelitian eksperimen. Untuk menganalisis data eksperimen yang menggunakan one group pre-test and post-test design.

Dari hasil pengujian hasil pre-test and post-test menunjukkan harga $\mathrm{t}_{\text {hitung }}$ sebesar 18.1. Sedangkan dari daftar distribusi diperoleh harga $\mathrm{t}_{\text {daftar }}$ atau $\mathrm{t}_{(0,995(19)}=2.86$. Ternyata harga $\mathrm{t}_{\text {hitung }}$ telah berada di dalam daerah penerimaan $\mathrm{H}_{\mathrm{A}}$. Dengan demikian dapat disimpulkan bahwa $\mathrm{H}_{\mathrm{A}}$ diterima dan tidak dapat menerima $\mathrm{H}_{\mathrm{o}}$. Jadi dapat disimpulkan bahwa latihan push-up dapat meningkatkan kemampuan lempar cakram pada cabang olahraga atletik, mahasiswa Jurusan Pendidikan Jasmani Kesehatan dan Rekreasi (PJKR) Fakultas Olahraga dan Kesehatan Universitas Negeri Gorontalo.

\section{UCAPAN TERIMA KASIH}

Terimakasih kepada Bapak Teguh Siswanto, SE selaku pembina dan pelatih utama PB. Hiqua Wijaya Kediri yang telah memberikan ijin untuk melakukan penelitian di PB. Hiqua Wijaya Kediri dan membantu pelaksanaan penelitian sehingga penelitian ini berjalan dengan lancar.

\section{KESIMPULAN}

Penerapan latihan push-up dapat memberikan kontribusi kemampuan lempar cakram. Hal ini dipengaruhi oleh hasil yang dilakukan setelah eksperimen, dalam hal ini dapat dikatakan 
bahwa latihan push-up dapat memberikan pengaruh yang baik terhadap kemampuan lempar cakram pada cabang olahraga atletik.

Setelah hasil analisis data pembahasan yang telah diuraikan pada bab sebelumnya maka dapat disimpulkan bahwa hipotesis yang berbunyi "Terdapat pengaruh latihan push-up terhadap kemampuan lempar cakram pada cabang olahraga atletik mahasiswa Jurusan Pendidikan Jasmani Kesehatan dan Rekreasi (PJKR) Fakultas Olahraga dan Kesehatan Universitas Negeri Gorontalo. " Dapat diterima .

\section{REFERENSI}

Boccia, G., Brustio, P. R., Moisè, P., Franceschi, A., La Torre, A., Schena, F., Rainoldi, A., \& Cardinale, M. (2019). Elite national athletes reach their peak performance later than nonelite in sprints and throwing events. Journal of Science and Medicine in Sport, 22(3). https://doi.org/10.1016/j.jsams.2018.08.011

Cahyono, C., Yarmani, Y., \& Arwin, A. (2018). Meningkatkan Teknik Dasar Lempar Cakram Dalam Proses Belajar Mengajardengan Menggunakan Media Modifikasi. KINESTETIK, 2(1). https://doi.org/10.33369/jk.v2i1.9180

Dai, A., Hadjarati, H., \& Haryanto, A. I. (2021). Gaya resiprokal untuk meningkatkan keterampilan shooting bola basket. Altius: Jurnal Ilmu Olahraga Dan Kesehatan, 10(1), 53-65. https://doi.org/http://dx.doi.org/10.36706/altius.v10i1.14056

Hadjarati, H., \& Haryanto, A. I. (2020). Motivasi Untuk Hasil Pembelajaran Senam Lantai. Multilateral Jurnal Pendidikan Jasmani Dan Olahraga. https://doi.org/10.20527/multilateral.v19i2.8646

Haryanto, A. I., Gani, A. A., Ramadan, G., Samin, G., Fataha, I., \& Kadir, S. S. (2021). Shooting Athlete Mental Training. JUARA: Jurnal Olahraga, 6(1). https://doi.org/https://doi.org/10.33222/juara.v6i1.1188

Sugiyanto. (2012). Dimensi Kajian Ilmu Keolahragaan. Sport Science, 1(1).

Wang, Y., Zhou, J., Deng, X., \& Zhong, S. (2018). Kinematic Analysis on the Final Exertion Motion of Elite Chinese Female Discus Throw Athletes. DEStech Transactions on Social Science, Education Human Science, emss. https://doi.org/10.12783/dtssehs/emss2018/24074 